\title{
Articles
}

\section{Contextual Analysis of Judicial Governance in Slovenia}

\author{
Matej Avbelj*
}

\begin{abstract}
What is a real character of judicial (self)-government in Slovenia? Does it live up to the standards established in a well-ordered society, based on the established rule of law and consolidated democracy? This certainly is an impression that an external critical, but uniformed, observer develops when he or she approaches the legal regulation of judicial (self)-government in Slovenia. This also is an impression that has been perpetuated in academic and professional circles prior and after the enlargement of the EU. The article dispels this myth. It does so by providing a comprehensive assessment of all the bodies and processes involved in the judicial (self)-government in Slovenia. Contrary to the prevalent formalistic legal approach, which dominates the legal scholarship concerned with judicial governance and the courts more generally, the article relies on a socio-legal methodological approach. It therefore situates the system of judicial self-government in the Slovenian socio-political context in order to provide an insight into how the judicial self-government really works and to what an extent it falls short of the normative ideals prescribed by the Slovenian positive law.
\end{abstract}

\footnotetext{
*Associate Professor of European Law, Faculty of Government and European Studies, New University, Slovenia; matej.avbelj@fds.nova-uni.si. The research leading to this article has received funding from the European Research Council (ERC) under the European Union's Horizon 2020 research and innovation programme (grant no. 678375-JUDI-ARCH-ERC-2015-STG). The paper is also prepared within the ARRS founded project on the Reform of the Rule of Law and Democracy in Slovenia J5-7359 (A).
} 


\section{A. Introduction}

What is a real character of judicial (self)-government in Slovenia? Does it live up to the standards established in a well-ordered society, based on the established rule of law and consolidated democracy? This certainly is an impression that an external critical, but uniformed, observer develops when he or she approaches the legal regulation of judicial (self)-government in Slovenia. This also is an impression that has been perpetuated in academic and professional circles prior and after the enlargement of the EU. There Slovenia has always been regarded as a good disciple and, consequently, as a role model for all the transitional countries that inspire to become the members of the EU in the foreseeable future.

The article dispels this myth. It does so by providing a comprehensive assessment of all the bodies and processes involved in the judicial (self)-government in Slovenia. Contrary to the prevalent formalistic legal approach, which dominates the legal scholarship concerned with judicial governance and the courts more generally, the article relies on a socio-legal methodological approach. It therefore situates the system of judicial self-government in the Slovenian socio-political context in order to provide an insight into how the judicial self-government really works and to what an extent it falls short of the normative ideals prescribed by the Slovenian positive law.

The argument is developed in four parts. The first part on the forms and rationalities of judicial self-government provides an in-depth description of the historical evolution and present arrangement of the modalities of judicial self-government in Slovenia. It seeks to acquaint the reader with the factual background necessary to comprehend the ensuing critical reflection on the shortcomings of a hence established system of self-government in practice. These shortcomings are analysed and illustrated in part two and three. They are concerned with the impact of judicial self-government on the independence, accountability, legitimacy, transparency and confidence in the judiciary, as well as with the repercussions of judicial self-government for the principle of separation of powers and the democratic principle. The article concludes by pointing to a yawning gap between the judicial self-government on books and the way it is really conducted in practice. It demonstrates how the remnants of the communist totalitarian past and the dense formal and informal networks in a relatively small Slovenian legal and political community have been used to manipulate the legal system of judicial self-government so to detract rather than to contribute to the values and principles associated with judiciary in a wellfunctioning constitutional democracy.

\section{B. Forms and Rationalities of Judicial Self-Government}

The Republic of Slovenia obtained its independence from the Socialist Federal Republic of Yugoslavia in June 1991. The act of self-determination of the Slovenian people was not 
motivated only by a desire to create an independent state. More importantly, this newly created state should have been of a fundamentally different quality than the one the Slovenian people decided to leave on a referendum in December 1990. Yugoslavia was neither based on the rule of law nor were the fundamental human rights and the national rights of the republics and autonomous provinces respected. ${ }^{1}$ The object and purpose of the Slovenian independence was thus a discontinuity with a totalitarian communist regime $^{2}$ and its replacement by a polity committed to the values of constitutional democracy. ${ }^{3}$ This qualitative change ought to be reflected also in the institutional structure of the newly independent state. The form should have been brought in compliance with the substance. ${ }^{4}$

On a general level, this has indeed been the case. Most importantly, the system of separation of powers (checks and balances) was created in lieu of the system of undivided powers existing under the totalitarian communist regime. ${ }^{5}$ This has, inter alia, introduced structural changes in the formal functioning of judiciary in Slovenia. The courts have become an independent, third branch of power. They were entrusted with a duty of ensuring judicial protection in fair trials conducted following due process of law, without undue delay, by independent and impartial courts constituted by law and composed of lawful judges. ${ }^{6}$ This was a normative requirement stemming from the newly adopted Constitution. Its fulfilment required a drastic change in the governance of the Slovenian judicial branch. The previously politically dependent judiciary, headed by the President of the Supreme Court who was simultaneously a functionary of the Communist party, had to be brought in compliance with the new constitutional order.

\footnotetext{
${ }^{1}$ Basic Constitutional Charter OJ RS, No. 11/1991.

${ }^{2}$ Constitutional Court Decision U-I-69/92 of 10 December 1992, para. 8 noting that Slovenia in Yugoslavia was a state "whose authorities had after the end of the war carried out mass executions of former military and current political opponents, legally unacceptable trials followed by death penalties, illegal seizure of property, obstruction and liquidation of political parties in violation of its own legal system etc., thus making the injured parties afraid, with good reason, for their lives in case of residing in such a country."

${ }^{3}$ Constitutional Court Decision U-I-109/10 of 3 October 2011, para. 18.

${ }^{4}$ For a good analysis that this normative objective continues to remain only partly realized, see Jan Zobec \& Jernej Letnar Černič, The Remains of the Authoritarian Mentality within the Slovene Judiciary, in CENTRAL EUROPEAN JUDGES Under the European Influence: The TRAnSformative Power OF THe EU Revisited (Michal Bobek ed., Hart, 2015); see also Matej Avbelj, Crises and Perspectives in Building a European Nation - The Case of Slovenia, in NATION's TRANSITIONS: SOCIAL AND LEGAL ISSUES OF SLOVENIA'S TRANSITIONS: 1945-2015 (SLOVENIA 1945-2015) (Peter Jambrek ed., 2014).

${ }^{5}$ Constitution, Art. 3.

${ }^{6}$ Constitution, Art 23.
} 
The introduction of judicial self-government in Slovenia was initially motivated purely by domestic reasons, to effectuate a qualitative transition to a constitutional democracy. However, the latter was also instrumental to obtaining membership in the Council of Europe and later in the European Union. The external incentives theory for developing judicial self-government therefore, at least in part, also provides an explanation for the Slovenian case. ${ }^{7}$ Finally, as the ensuing discussion will demonstrate, the way the judicial self-government in Slovenia de facto works also fits well the judicial leadership theory. ${ }^{8}$

The judicial (self)-government in Slovenia is exercised through a complex web of checks and balances. This is constituted of a triangle of the three branches of power: the judicial, the executive and the legislative branch, alongside with a sui-generis institution: the Judicial Council. The latter is the main body of judicial self-government stricto sensu. The judicial self-government lato sensu is thus divided between the Judicial Council and the Judicial Administration that is carried out by the courts themselves and, in particular, by the presidents of the courts, who are sometimes assisted by the court's Director, ${ }^{9}$ in cooperation with the Personnel Councils. The managerial and administrative position of the presidents of the courts is very strong. They are responsible for an overall sound management of their respective courts. They make preliminary selection of individuals to be appointed as judges by the National Assembly upon the proposal by the Judicial Council. Moreover, the presidents of the courts are also chairing the Personnel Councils. The latter are organs composed of several influential judges who exercise peer-review and rate their colleagues' work to, finally, make recommendations to the Judicial Council as to the career development of individual judges.

The Ministry of Justice carries political responsibility for the functioning of the judiciary. It must ensure a sufficient judicial budget and it drafts the legislative and adopts the administrative framework for the functioning of the judiciary. More recently, the Ministry has also started exercising an administrative oversight of the judiciary through the Office for the Supervision of Court Management. ${ }^{10}$ Finally, the National Assembly adopts the legislative framework, decides on the courts' budget and, most importantly, appoints all the judges. It also elects the President of the Supreme Court who is the head of Judicial Administration of Slovenia and represents the judiciary in public as well as in relationship with the other two branches of power. The following figure sketches the main bodies of judicial (self)-government in Slovenia. They and their competences will be described in more detail below.

\footnotetext{
${ }^{7}$ See, for example, Petra Guasti, Bojan Dobovšek \& Branko Ažman, Deficiencies in the Rule of Law in Slovenia in the Context of Central and Eastern Europe, 14 VARSTVOSLOVJE 175-190 (2012).

${ }^{8}$ David Kosar, Perils of Judicial Self-Government in TRANSitional Societies (2016).

${ }^{9}$ Courts Act, Art. 61, 61b.

${ }^{10}$ Courts Act, Art. 65.
} 
Figure 1: Judicial (Self)-Government in Slovenia

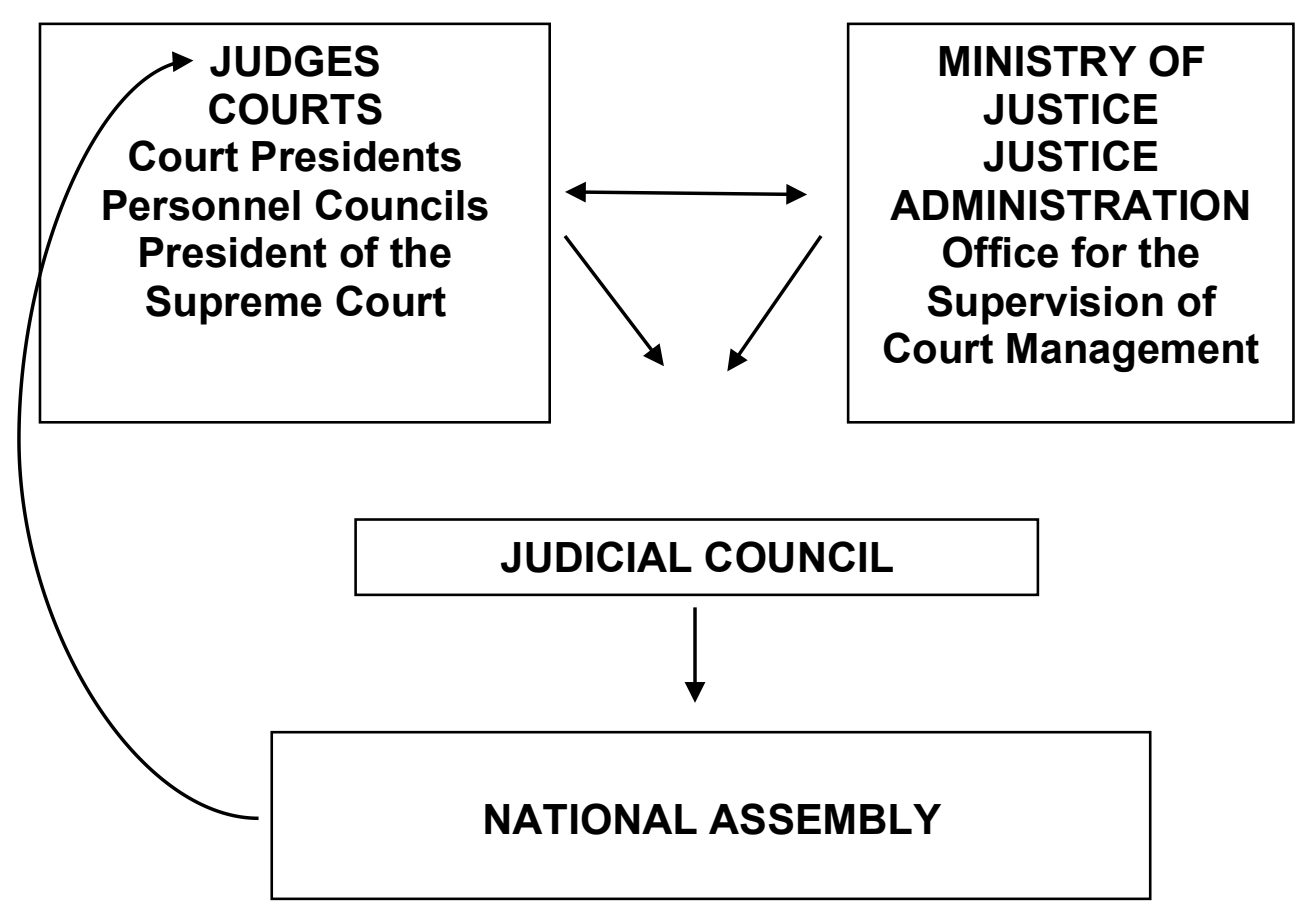

In the anticipation of the qualitative change of the regime, the Judicial Council [Sodni svet] was established already in 1990, before the independence and while the democratic transition only started taking shape. ${ }^{11}$ It was composed of nine members: five judges, three lawyers of high reputation and the then minister of justice. All of them, other than the minister who was a member ex lege, were appointed by the socialist National Assembly [Skupšcina]. The role of the hence established Judicial Council was very limited, if not even negligible. It was consulted on the issues relating to the management of the courts' personnel. ${ }^{12}$ However, despite its circumscribed role, the Judicial Council was a harbinger of the model of judicial self-government to be established with the adoption of the new Constitution [Ustava] in December 1991.

\footnotetext{
${ }^{11}$ ZVONKO FIŠER, SODNI ALI PRAVOSODNI SVET, V NORMATIVNE SPREMEMBE NA PODROČJU SODSTVA V REPUBLIKI SLOVENIJI (2001).

${ }^{12} / d$.
} 
The Constitution, and on its basis two systemic laws regulating the judiciary: The Courts Act [Zakon o sodiščih] ${ }^{13}$ and The Judicial Service Act [Zakon o sodniški službi], ${ }^{14}$ established the judiciary as an independent branch of power, in principle fully in compliance with the then and now existing comparative constitutional and international standards for the functioning of the judiciary. This new, modern and up to date constitutional status of judiciary, which was also adopted with an eye on the desired accession of Slovenia to the Council of Europe and the European Union, enjoyed a unanimous support of the political parties and the legal expert community. Similarly, there has always been a consensus that the independent functioning of the judiciary requires the existence of a special sui generis body, which would ensure that the judiciary complies with the constitutional requirements and that the two other branches of power do not interfere with it. However, views were split on the precise nature, composition and competences of such a body.

Some legal experts argued in favour of a justice council broadly conceived of. This would regulate not just the status of judges, but also of other actors in the justice system, in particular the status of the prosecutors. This view remained in a minority and eventually a judicial council competent exclusively for judges was established. As this issue had been resolved, the decision had to be taken whether the judges should be in the majority in the hence established council or, alternatively, should their powers and the potential for judicial corporatism be counterbalanced and offset by other legal professionals, most notably academics and the representatives of lawyers in private practice. Politically this debate has never really been settled. The post-communist centre-right political parties, in particular, continue to insist that the judicial majority in the Judicial Council is too often used as a self-serving measure by the judges. Also the former Constitutional Court Justice Matevž Krivic has repeatedly argued that the majority of judges in the Judicial Council should be replaced by the majority of those nominated by the National Assembly, also to ensure a more democratic control over the judiciary. ${ }^{15}$ However, the Constitution legally pre-empted this debate at a very early stage.

Art. 131 of the Constitution, which has established a Judicial Council, stipulates that the latter is composed of eleven members, among which six are elected by the judges and five of them by the parliament: the National Assembly [Državni zbor] upon the proposal by the President of the Republic. The Slovenian Judicial Council is, as the Constitutional Court has also confirmed, a sui generis body, independent of the legislative and the executive branch and it does not represent the judges either. ${ }^{16}$ The Constitution endows the Judicial Council

\footnotetext{
${ }^{13}$ OJ RS 94/07.

${ }^{14}$ OJ RS 94/07.

${ }^{15}$ Matevž Krivic, Drugačno mnenje o volitvah sodnikov, 37-38 PRAVNA PRAKSA 12-13 (2002).

${ }^{16}$ Constitutional Court of Slovenia Case U-I-224/96, par. 11: "The Council of the Judiciary is thus an organ which performs a specific role in constituting judicial power and according to the valid statutory arrangement, generally decides on questions which affect the legal position of judges. From the point of view of the organisation of state
} 
with only two, albeit important competences. The judge can be appointed or dismissed, in case of a serious violation of judicial duties, only upon the proposal of the Judicial Council. ${ }^{17}$ This constitutional solution enjoys an unequivocal political and expert support in Slovenia. However, this is certainly not the case with regard to the constitutional actor, which disposes with the proposals of the Judicial Council.

It is a Slovenian particularity that the judges are appointed and dismissed by the National Assembly. As this carries a risk of politicization of the judiciary, that the framers of the Constitution were, of course, aware of, it needs to be explained why they opted for this solution. There are two main reasons for it and while they are both connected to the legacy of the preceding communist regime, they are in fact mutually contradicting. The appointment of judges by the National Assembly is a relic of the system of undivided powers, existing under communism. This was appealing to the Slovenian political left, which has evolved from the former communist party and has never entirely parted with symbolical as well as some organizational features of the preceding communist regime. At the same time, the centre-right post-communist parties also endorsed this solution. On the one hand, they did so because this solution strengthened the sovereignty of the people represented in the National Assembly, which was in line with the then post-independence referendum democratic euphoria of "we the people." However, a more important reason for not conferring the competences of appointment and dismissal of judges on the president of the republic, as is the case in most parliamentary systems, was a huge distrust of the presidential powers which were to be wielded by the last chief of the Communist party, Milan Kučan, who was elected as a President of the independent Slovenia. Political ad personam considerations thus led to a specific Slovenian system of appointment and dismissal of judges by the National Assembly which has, as will be discussed in more detail below, in part two, recently proven to be quite problematic.

With few exceptions, ${ }^{18}$ the system of appointment of judges by the parliament has been criticized by the legal academia. ${ }^{19}$ Under the impact of this criticism, in 2001 the then government proposed an amendment to the Constitution which would, now when the Office of the President was no longer occupied by the former chief of the Communist party, transfer the competences of appointment and dismissal of judges from the National Assembly to the President of the Republic. However, the amendment has never been

power, the Council of the Judiciary is a special organ (state organ sui generis) which cannot be classified into any of the three branches of power." Such is also a self-description by the Judicial Council...

${ }^{17}$ Constitution, Art. 130, 132.

18 Jernej Letnar Černič, Kako izvoliti sodnike, lus Kolumna (Aug. 19, 2016); Tone Jerovšek, Ustavna ureditev sodstva, VII. Dnevi javnega prava, No. 1/2001, p. 47-59.

${ }^{19}$ Marko Novak, Nevarno razmerje: politika nad Sodnim svetom, lus kolumna (Oct. 24, 2016); also Marko Novak, Volitve sodnikov - mora Slovenija ostati evropska izjema?, lus kolumna (Aug. 29, 2016). 
adopted. As with other relicts of the system of undivided powers, which entrust a lot more powers to the National Assembly than this is the case in the classical parliamentary systems, it became clear that it would be extremely hard, perhaps impossible, to convince the National Assembly to divest itself of any powers that it presently has, no matter how disruptive for a sound functioning of the Slovenian constitutional system they are. ${ }^{20}$

The limited scope of powers conferred on the Judicial Council by the Constitution has been significantly extended by the legislation. In 2017 a Judicial Council Act [Zakon o sodnem svetu] ${ }^{21}$ was adopted, so that the organization, financing, competences and procedures of this special body are now regulated in its own statute. This distinguishes between four main groups of competences of the Judicial Council. The first scope of competences pertains to the selection, appointment and dismissal of judges, presidents and vicepresidents of the courts. ${ }^{22}$ The second concerns other issues of staff policy. ${ }^{23}$ The third group of competences provides for the Judicial Council's role in the disciplinary procedures. The fourth group authorizes the Judicial Council to execute other tasks. ${ }^{24}$

As part of the first group of competences, the Judicial Council is authorized to deliver a preliminary opinion in the process of appointment of the president of the Supreme Court; ${ }^{25}$ to propose the candidates for the position of the Supreme Court Judge to the National Assembly; to appoint and to dismiss the presidents and vice-presidents of all courts, other than the Supreme Court; to select the candidates for a vacant judicial post; to propose the candidates for the appointment as a judge to the National Assembly; to appoint an already elected judge to the advertised judicial post; to prepare a reasoned opinion in the process of dismissal of the president of the Supreme Court; to notify the National Assembly about a final conviction of a judge; to propose to the National Assembly a dismissal of a judge; to issue a declaratory decision on the termination of the judicial function.

With regard to the second group of competences pertaining to other staff-policy issues the Judicial Council decides on the incompatibility of the judicial function; on the question of promotion to a higher judicial title, to a higher salary class, to a position of a judge councillor, to a higher judicial position or on the extraordinary promotion. The Judicial

\footnotetext{
${ }^{20}$ Matej Avbelj, Sistem demokratične neodgovornosti, lus kolumna (Apr. 22, 2016).

${ }^{21}$ OJ RS 23/17.

${ }^{22}$ Judicial Council Act, Art. 23/1.

${ }^{23}$ Id., Art. 23/2.

${ }^{24}$ Id., Art. 23/4.

${ }^{25}$ The president of the Supreme Court is appointed by the National Assembly upon the proposal of the Minister of Justice.
} 
Council also approves the negative evaluation of a judge and decides on the complaints of judges regarding their status' issues. It also decides on the relocation of a judge, as well as on other staff related issues determined by the law. ${ }^{26}$

The Judicial Council further nominates the disciplinary organs, initiates the disciplinary procedure and executes the disciplinary sanctions as part of its disciplinary competences. ${ }^{27}$ Prior to the adoption of the Judicial Council Act the disciplinary procedures were carried out by the judiciary itself through its special disciplinary bodies. Between 2010 and 2016 there were 22 disciplinary proceedings initiated and they reached the following outcome: ${ }^{28}$

Table 1: The Supreme Court 2016 Annual Report.

\begin{tabular}{|l|l|l|l|l|l|l|l|}
\hline & 2010 & 2011 & 2012 & 2013 & 2014 & 2015 & 2016 \\
\hline $\begin{array}{l}\text { Number of } \\
\text { cases }\end{array}$ & 0 & 7 & 1 & 1 & 3 & 7 & 3 \\
\hline Acquittal & 0 & 2 & 1 & 0 & 0 & 3 & 1 \\
\hline $\begin{array}{l}\text { Dropping of the } \\
\text { case (judge left } \\
\text { the office) }\end{array}$ & 0 & 0 & 0 & 0 & 2 & 0 & 0 \\
\hline $\begin{array}{l}\text { Transfer of a } \\
\text { judge }\end{array}$ & 0 & 0 & 0 & 0 & 1 & 0 & 0 \\
\hline Written warning & 0 & 3 & 0 & 1 & 0 & 0 & 1 \\
\hline Salary decrease & 0 & 0 & 0 & 0 & 0 & 2 & 0 \\
\hline $\begin{array}{l}\text { Suspension of } \\
\text { promotions }\end{array}$ & 0 & 2 & 0 & 0 & 0 & 2 & 1 \\
\hline
\end{tabular}

Among the so-called other competences, the Judicial Council, after having consulted the Minister of Justice, adopts the criteria for the selection of judges, as well as the criteria for evaluating the quality of judge's work. The Judicial Council also adopts the ethical code for judges and appoints the members of the Commission for ethics and integrity. Finally, the Judicial Council needs to be consulted in the matters of organizational scheme of the courts, in determining the number of judicial positions in a court, as well as in the process of adoption of the laws regulating the courts and judicial service. The Judicial Council also provides its opinion on the annual report of judicial activities prepared by the Supreme Court. It can require a review of management of a particular case, as well as it gives its opinion in case of detention or initiation of a criminal procedure against a judge. Last but

${ }^{26}$ Art. 23.

${ }^{27}$ Art. 23/3.

${ }^{28}$ The Supreme Court 2016 Annual Report, figure 56, at 103, http://www.sodisce.si/mma_bin.php?static _id $=2017051514342635$. 
not least, the Judicial Council Act has newly authorized the Judicial Council to initiate a constitutional review before the Constitutional Court with regard to the regulations impinging on the constitutional status and role of the judiciary. ${ }^{29}$ Upon the request of the Minister of Justice or the President of the Supreme Court, the Judicial Council also prepares a report on the matters falling within the scope of its competences and subject to public interest. $^{30}$

It follows from the statutory regulation of the Judicial Council that its scope of competences is broad. They relate to almost all dimensions of judicial activity. However, this de jure relatively strong position of the Judicial Council is not necessarily a sign of its actual powers in practice. To the contrary, the Judicial Council as an institution has been very weak, since its formal powers have never been matched by an internal organizational structure that would enable its efficient functioning in practice. ${ }^{31}$ The membership in the Judicial Council is only honorary. The new Act on the Judicial Council, despite the praise it has received in the expert community, ${ }^{32}$ has left this intact. Other than a tiny secretariat, no one else conducts her role in the Judicial Council professionally, not even its president. In practice, this means that the sessions of the Judicial Council take place in the afternoon, or during the breaks, when its members are on leave from their quotidian occupations, and they devote a little bit of their extra time to the constitutionally mandated overall management of the Slovenian judiciary.

Of course, realistically this cannot be done. It would be impossible to execute all these important competences as a part time job, let alone as an honorary appointment. But since these competences need to be, and indeed are, executed in practice, this means that the centre of decision-making, the de facto source of the decisions formally taken by the Judicial Council must be elsewhere. It must be sought at a preparatory level, e.g. on the level of organs that prepare the files and draft the decisions for the adoption by the Judicial Council. These organs are the Personnel Councils [personalni svet] established at the District Courts, the Courts of Appeals and at the Supreme Court. ${ }^{33}$ The Personnel Council is composed of a president of the court and $\operatorname{six}^{34}$ or four judges, ${ }^{35}$ who are elected

\footnotetext{
${ }^{29}$ Art. 23/4.

${ }^{30}$ Art. 24

${ }^{31}$ Marko Novak, Institucionalna podhranjenost slovenskega sodnega sveta, 23 PRAVNA PRAKSA 17 (2013).

${ }^{32}$ Marko Novak, ZSSve, lus kolumna (May 15, 2017); for a critique, see Matej Avbelj, Legalistična naivnost, lus kolumna (July 17, 2017).

${ }^{33}$ Courts Act, Art. 30.

${ }^{34}$ District Court Personnel Council.

${ }^{35}$ Court of Appeals and the Supreme Court Personnel Council.
} 
by the judges themselves. ${ }^{36}$ Its role is to evaluate the quality of judicial service of the judges at the inferior courts and rule on their complaints against the evaluations hence prepared. $^{37}$ The judicial ratings prepared by the Personnel Council are an example of a judicial peer-review, which influences the judges' chances of promotion and hence determines the prospects for his or her entire career. While formally the Personnel Councils can make no binding decision on judge's promotion and career development, since these decisions belong to the Judicial Council, in practice the Personnel Councils, and presidents of the courts as their chairs, are extremely influential. In many ways, it is them rather than the Judicial Council, who take the decision. The best evidence produced so far can be found in a letter of resignation by a former member of the Judicial Council.

In 2003, Ms Nevenka Šorli, an attorney at law, resigned from the Judicial Council protesting that the latter is merely a rubber-stamping institution: "in practice the decisions on the promotion of judges are mostly already made by the personnel councils. There, however, it is more than apparent that the decisions are shaped by the principles of solidarity between judges and not to disappoint one's colleague." ${ }^{38}$ The decisions on the (re-)appointment of the court's (vice)-presidents were, according to her, adopted in a similar way: "It is already an old practice that it is clear in advance that an incumbent (vice)-president of a court, if he or she decides to run again, will be reappointed, irrespectively of the actual results achieved under his or her presidency. This causes that other judges, probably again out of solidarity and tactfulness, do not decide to apply, but if they do, they are, as a rule, unsuccessful." 39 The system of judicial self-government is thus de facto bent in favour of the Personnel Councils, composed of influential judges, among which the courts' presidents play the most important role.

As convincingly argued by Vavken, ${ }^{40}$ the too frequent and often unnecessary reforms of the legislation regulating the judiciary in Slovenia have incrementally strengthened the de facto already preeminent role of the presidents of the courts. It is not unusual for a president of the court, including a President of the Supreme Court, to simultaneously sit on and chair the Judicial Council. ${ }^{41}$ In this way, the court presidents strengthen their formal as well as informal influence even further by being in charge of the judicial administration of

${ }^{36}$ Courts Act, Art. 32, 33.

${ }^{37} / d$.

${ }^{38}$ Nevenka Šorli, Odstopna izjava članice Sodnega Sveta, 20 ODVETNIK 31 (2003).

${ }^{39}$ Id.

${ }^{40}$ Luka Vavken, Delovanje in upravljanje sistema rednega sodstva (Master Thesis, University of Ljubljana Faculty of Law, 2016).

${ }^{41}$ This was the case of Mr Masleša prior to and some time after his appointment as a President of the Supreme Court. 
an individual court, by exercising control over a selected Personnel Council and ultimately by taking part in or even running the Judicial Council. In so doing, a centralized, hierarchical structure of judicial governance has been created, on the basis of which the courts and individual judges are tightly managed and closely controlled by a leading structure composed of the presidents of the courts, chairs of sections, departments and their deputies. ${ }^{42}$

Most importantly, the presidents of the courts play a very strong role in the appointment of judges. They prepare a preliminary reasoned selection of the best candidates for an advertised judicial position and submit the list for the nomination to the Judicial Council. ${ }^{43}$ The presidents of the courts can thus de facto filter who enters the judiciary. They also decide on the promotion of a judge in salary class ${ }^{44}$ and play a leading role in the evaluation of a judge by the Personnel Council. The evaluation is conducted every third year, other than for the judges beginners who are evaluated on an annual basis in the first three years of their service. Despite the fact that the presidents of the courts have only one vote in the Personnel Councils, the latter are, in effect, run by the presidents of the courts. This is due to their official authority and because of the informal influence they wield in a 'bureaucratic' judicial structure, characterized by a collectivist judiciary as opposed to the one which is a sum of personally independent judges.

The system of judicial self-government thus de jure, but especially de facto, strengthens the leading judicial cadre, in particular the presidents of the courts. Not just external observers, but also Supreme Court justices themselves have therefore warned against the emerging judicial oligarchy, which exposes the Slovenian judiciary to notable risks of judicial corporatism. Moreover, the hence established strict hierarchy of judicial organization is closely modelled on the organization of public administration. The Supreme Court under the leadership of its President executes a plethora of tasks related to judicial administration ${ }^{45}$ that are in other countries either in the hands of the executive branch or exercised by the judicial councils. ${ }^{46}$

${ }^{42} / d$., at 67 .

${ }^{43}$ Court Service Act, Art. 16 .

${ }^{44}$ Court Service Act, Art. 28.

${ }^{45}$ Courts Act, Art. 60 stipulates that Judicial Administration, that the courts' presidents are responsible for, consists of: decision-making, knowledge-managament, planning, organization, staff-managament, leading, coordination, communication, monitoring the effects, reporting, managing the court's budget as well as all other tasks prescribed by the law. Moreover, according to Art. 60a it is also part of judicial administration to monitor, determine and analyze the efficiency of judges' work at the individual courts.

${ }^{46}$ Some Supreme Court justices themselves have been critical of the present system, see Mateja Končina Peternel, Kakšne pristojnosti (naj) ima Sodni svet?, 7-8 PRAVNA PRAKSA 6-7 (2015). 
The judicial service is thus increasingly permeated by the administrative mind-set on whose basis the entire judiciary, more and more, functions as an administrative branch too. ${ }^{47}$ This is reflected in the subjugation of judges to their hierarchical superiors who exercise a close administrative and formal control especially over the quantity, rather than quality, of the work done by individual judges. This bureaucratic mentality, which goes against the grain of a personal independence of an individual judge, has been so widespread that it has recently even found its expression in the EU-funded project run by the Supreme Court. The project, which carries an indicative title: "Let's judge together", implements a mentoring program for the newly appointed judges by the superior judges so to ensure that the newcomers will get quickly accustomed to the modalities of the system. This pressure to socialize every single individual judge under the overall expectations of the judicial system, as determined by the ruling judicial cadre, builds on a model of judiciary characteristic for socialism and its system of undivided powers. ${ }^{48}$ The absence of a professionally run judicial academy, which is compensated for by a rather fragmented and ineffective continuing judicial education under the auspices of the Ministry of Justice, contributes further to this effect. All in all, the above-described developments have produced a tense climate of constant pressure, ${ }^{49}$ which has since had a negative impact on the independence, accountability, legitimacy, transparency and public confidence in the judiciary.

\section{The Impact of Judicial Self-Government on the Independence, Accountability, Legitimacy, Transparency of and Confidence in the Judiciary}

Judicial independence is a paramount constitutional value related to the status, role and functioning of the Slovenian judiciary. There is a widespread agreement in Slovenia that in purely legal terms the judicial independence enjoy a sufficient degree of structural protection. However, from the very beginning the National Assembly's right to appoint judges has been critiqued as being incompatible with judicial independence or posing a threat to it. Until recently, this claim has not been supported by practical evidence, as the National Assembly has exercised its power of appointment more as a notary duty, ${ }^{50}$ by almost automatically, without any substantive discussion, confirming the candidates proposed by the Judicial Council. ${ }^{51}$ Yet, in 2015 the National Assembly unanimously refused the proposal of the Judicial Council to appoint a practicing attorney at law as a

\footnotetext{
${ }^{47}$ Vavken, supra note 40, at 67; Marko Šorli, Dialog za zaupanje in spoštovanje, 24-25 PRAVNA PRAKSA 6-7 (2008).

${ }^{48}$ Matej Avbelj, Zakaj ne sodimo skupaj?, Finance (Nov 25, 2017), https://www.finance.si/8862512.

${ }^{49}$ Vavken, supra note 40, at 67; Marko Šorli, Dialog za zaupanje in spoštovanje, 24-25 PRAVNA PRAKSA 6-7 (2008).

${ }^{50}$ Vavken, supra note 40 , at 101.

${ }^{51}$ Tone Jerovšek, Ustavna ureditev sodstva, VII. Dnevi javnega prava, št. 1/2001, p. 53, who reports that in the first ten years of the Slovenian independence the National Assembly refused to appoint three candidates, which were eventually nevertheless appointed upon the repeated proposal by the Judicial Council.
} 
Court of appeals judge. Later in 2015 , it also refused by an ordinary majority to elect an acting court of appeals judge to the Supreme Court.

The Judicial Council argued that this was a violation of the independence of judiciary as well as of the rule of law. In order to prevent the ongoing politicization of the judiciary it called for the amendment of the Constitution and the applicable laws to strip the National Assembly of its present powers. ${ }^{52}$ The expert community and the general public at large remained divided about the conduct of the National Assembly. Some viewed it as an exercise of checks and balances, ${ }^{53}$ while others claimed that this was indeed an interference with the independence of the judicial branch. ${ }^{54} \mathrm{~A}$ similar division exists about the recently introduced Office for the Supervision of the Management of the Court [Služba za nadzor organizacije poslovanja sodišč ${ }^{55}$ Established within the Ministry of Justice and headed by a judge specifically designated to this post by the Judicial Council, ${ }^{56}$ it is authorized to review the administrative management of the courts ensuring that the quality standards prescribed by the law are met. ${ }^{57}$ The judiciary and several legal experts have been very critical of this measure. They insisted that as the line between the administrative and substantive supervision can be easily blurred, the office for the Supervision violates the independence of the judiciary and is hence even unconstitutional. ${ }^{58}$ The Ministry, on the other hand, has argued that the measure is both appropriate and necessary to address the administrative ineffectiveness of the courts. As such it has been defended as being part of the executive branch's responsibility to ensure efficient and high quality functioning of the courts.

Other than by the existing constitutional and legislative framework, the de jure judicial independence has also been strengthened by the jurisprudence of the Constitutional Court. The Court has thus declared unconstitutional a proposed salary reform which could, by introducing a stimulus for more productive judges, reduce the salaries of other judges or put them in an unequal position with other branches of power in terms of their remuneration. $^{59}$ In this way, the Constitutional Court has striven to ensure that the

\footnotetext{
${ }^{52}$ http://www.sodni-svet.si/2016/tiskovno-sporocilo-izjava-za-javnost-sodnega-sveta-z-dne-25-11-2016/.

53 Jasna Murgel, Nedopusten poseg v sodstvo? Strah je odvečl, 16 PRAVNA PRAKSA 12-13 (2015).

${ }^{54}$ See, for example, Matevž Krivic, Se poslanci res imajo sposobne sodniškega odločanja?, 7-8 PRAVNA PRAKSA 20-21 (2015).

${ }^{55}$ http://www.mp.gov.si/si/delovna_podrocja/sluzba_za_nadzor_organizacije_poslovanja_sodisc/.

${ }^{56}$ This position is currently held by a designated judge Miran Jazbinšek.

${ }^{57}$ Courts Act, Art. 65a.

${ }^{58}$ Vavken, supra note 40 , at 81.

${ }^{59}$ Constitutional Court U-I-60/06; U-I-159/08. For a comment, see, Gregor Virant, Sodstvo - močna veja oblasti in hkrati učinkovit servis, 3 PRAVNA PRAKSA 6-7 (2007).
} 
economic independence of judges is also safeguarded. The government moved to implement the ruling of the Constitutional Court, but the judges, under the leadership of the Association of Judges [Sodniško društvo], turned the salary offer down and went on strike for several months in 2008 and 2009. The Judicial Council refused to support the strike and therefore came under a judicial critique. On the other hand, the Association of Judges was seen by many as a "judges' trade union [...] the bulk of its activity being linked to salary bargaining." ${ }^{\prime 00}$ The controversy was ultimately resolved in favour of judges.

If the model of judicial self-government has created fairly little controversies with regard the de jure independence of Slovenian judiciary, the same cannot be said about the de facto independence and the outcome independence. From the outset, the objections have been made against the Slovenian judiciary that it lacks a de facto political independence. This claim has been substantiated by the absence of lustration. ${ }^{61}$ While the Slovenian legislation provided for a limited lustration clause, on whose basis the judges who actively violated human rights in the previous regime could not be reappointed in the independent Slovenia, the clause essentially remained ineffective. Consequently, basically all judges from the communist regime, who so willed and desired, were appointed, without much actual scrutiny, to permanent judicial posts in the independent Slovenia. This outcome could be also, at least to a certain extent, contributed to the judicial self-government existing at the time, which, in the spirit of collegiality, ensured that the lists of judges, rather than individual names, would be voted on in the National Assembly.

As colourfully explained by one of the former presidents of the Judicial Council, the latter at the time acted as judge-making factory, which was en masse turning the previously socialist judges with a limited tenure into democratic judges with a permanent tenure. ${ }^{62}$ Combined with the fact, that the Slovenian justice system failed to prevent or at least sanction the economic criminal activities which in the process of transition imposed huge costs on the previous social property and now on the tax-payers, and given that the most prominent actors in the crony capitalist transition were the members of the former communist elite, a wide spread sentiment has grown in the population, fuelled by the centre-right post-communist political parties, that the judiciary is under the influence of the former communist nomenclature, indeed its part and in service of its interests. This

\footnotetext{
${ }^{60}$ Cristina Dallara, Democracy and Judicial Reforms in SOUth-EASt Europe (2014) 39.

${ }^{61}$ See further Zobec and Letnar, supra note 4, who point out that the entire body of lawyers was implicated in the previous regime and quote the following fitting paragraph by France Bučar: "with their often unnecessary or at least excessive meekness [...] they themselves have strengthened the totalitarian system, as by their conduct and laxness they were giving it justification of at least acceptability, if not legitimacy, and thus inadvertently confirming that it is right and simultaneously giving it an absolution for its violations of fundamental human rights." France Bučar, 'Pravnik v današnjem času' (uvodno predavanje na 30. Dnevih slovenskih pravnikov) [Lawyer in the Current Times, The Introductory Lecture at 30th Days of Slovene Lawyers], 36 PRAVNA PRAKSA 6 (2004).

${ }^{62}$ Alenka Leskovic, Deset let pozneje, 18 PRAVNA PRAKSA 33 (1999).
} 
sentiment has been accentuated further by the fact that the country has been for most of the time since its independence ruled by the centre-left political parties which have been, either directly or indirectly, descendants of the former communist elite. ${ }^{63}$ This has prompted the beliefs that Slovenia is a captured, perhaps even a (post)-communist mafia state. The judges themselves have ignited these beliefs. Thus, for example, the President of the District Court of Ljubljana took part in a concert dressed up as a Tito's pioneer, wearing a red communist star and waving with a Yugoslav communist flag. The Judicial Council's reaction to her behaviour was extremely lukewarm, issuing no more than a public warning that judges should protect their independence, while her colleagues rushed to defend her right to use her free time and privacy as she finds it fit. ${ }^{64}$

However, it has been the appointment of Mr Branko Masleša in 2010 as a president of the Supreme Court, that has, besides the already mention judicial strike related to the salary dispute and the notorious Patria case ${ }^{65}$ had the most negative impact on the overall integrity of the Slovenian judiciary, both in objective and subjective (i.e. perceived) terms. $\mathrm{Mr}$ Masleša was a highly controversial political and legal figure. The centre-right postcommunist parties claimed that before the independence he was, as a local communist functionary and a criminal judge in Koper, an avid supporter of the Yugoslav Army and a critic of the independence movement. He also took part in a trial that rendered the last death-sentence verdict in the Socialist Republic of Slovenia. Also, public charges were made against him that during the communist regime he participated at verifications of killings of renegades on the Yugoslav - Italian border. ${ }^{66}$ For these reasons, Mr Masleša faced considerable hurdles in the process of his appointment to the Supreme Court in 2000. The National Assembly refused his candidacy and appointed him only after his candidacy was resubmitted by the Judicial Council. The then president of the Judicial Council, Marko Pavliha, wrote a highly emotional and critical letter in defence of Mr. Masleša, praising him as an extraordinary expert in criminal law with more than 20 years of experience. ${ }^{67} \mathrm{~A}$ few years later, Mr Masleša became a president of the Judicial Council and in 2010, while still presiding over the Judicial Council, he was appointed as a President of the Supreme Court. Before his appointment, the public charges from 2000 were stressed again and were this time even corroborated by the Constitutional Court Justice and two Supreme Court judges. However, the Judicial Council, then chaired by the later Prime

\footnotetext{
${ }^{63}$ Frane Adam \& Matevž Tomšič, Transition Elites: Catalysts of Social Innovation or Rent Seekers?, (2000); Bojan Bugarič, Crisis of Constitutional Democracy in Post-Communist Europe: "Lands In-between" Democracy and Authoritarianism, 13 INT'L. J. OF CST. L. 229 (2015).

64 Špelca Mežnar, Zasebno življenje sodnice, 20 PRAVNA PRAKSA (2014).

${ }^{65}$ See the discussion infra; for a broader overview, however, see Matej Avbelj, Failed Democracy: The Slovenian Patria Case - (Non)Law in Context. Available at SSRN: https://ssrn.com/abstract=2462613 (July 4, 2014). Originally published in Slovenian as Matej Avbelj, Zadeva Patria - (ne)pravo v kontekstu, 26 PraVNA PRAKSA (2014).

${ }^{66}$ Mr. Masleša has, however, repeatedly refuted these allegations as false and malicious.

${ }^{67}$ Marko Pavliha, Primer Masleša: (ne)uspeh Sodnega sveta?, 7 PRAVNA PRAKSA 4-6 (2000).
} 
Minister Miro Cerar, dismissed these public statements as too late to be accounted for in the appointment procedure ${ }^{68}$ and reprimanded the critical judges for disrespect of their professional ethics. $^{69}$

A few years later, then already as a President of the Supreme Court, Mr Masleša was presiding over a criminal chamber at the Supreme Court which convicted Mr Janez Janša, a president of the main opposition political party, for having accepted the promise of an unknown award at a vaguely determined time, at an undetermined place and by an undetermined mode of communication to use his influence, then as Prime Minister, to have a military contract awarded to the Finnish company Patria. ${ }^{70}$ The case was from the very beginning conducted in an extremely unusual way, raising suspicions that this was a politically motivated persecution of the main political opponent. The case started by way of a direct indictment and hence avoided the procedural guarantees of an appellate review that an ordinary indictment is subject to. The indictment was brought by a state prosecutor who is a wife of an agent of the Slovenian communist secret-service police that arrested Mr. Janša as a political dissident during the reign of the communist regime in the late 1980s. The trial on all instances lasted for almost a decade and it had through media orchestration distortive effects on three general elections to the National Assembly, local elections as well as elections to the European Parliament. ${ }^{71}$

In the meantime, a Higher Court judge, Vesna Rakočević Bergant, in her academic extrajudicial writing publicly congratulated the District Court judge for the courageous sentencing (then not yet final) of the accused. ${ }^{72}$ She likened the protest of the supporters of the sentenced in front of the court to the hysterical reactions of North Korean children at the visits of Kim Jong Un. ${ }^{73}$ Mr. Masleša, however, added his part too with a thunderous performance in front of a crowd of judges gathered at the annual event "Days of Judiciary". He used that occasion for tirades against both the defendant, who at the time had an open deadline for a request for extraordinary legal remedy at the Supreme Court, as well as against one of the Constitutional Court judges. In addition, the very same supreme public prosecutor who achieved the final sentence in the Patria case was taking part at the event. $^{74}$

\footnotetext{
${ }^{68}$ However, the charges have been publicly known for more than 10 years.

${ }^{69}$ Sodni svet, Zavarovanje dostojanstva in sodnikov in sodstva, 49-50 PRAVNA PRAKSA 36 (2010).

${ }^{70}$ For an in-depth analysis of the case MATEJ AVBEL, NePRAVNA DRŽAVA (2015).

${ }^{71}$ Matej Avbelj, How to Reform the Rule of Law in Slovenia, in SLOVENIA: SOCIAL, ECONOMIC AND ENVIRONMENTAL ISSUES (Frane Adam ed., 2017).

${ }^{72}$ Vesna Rakočević Bergant, Zakaj meni nihče ne piše sodb v Murglah?, 23 PRAVNA PRAKSA 33 (2013).

${ }^{73} / d$., at 33 .

${ }^{74}$ See, the official report from the event, at http://www.sodisce.si/vsrs/objave/2014060616053789/.
} 
The final ruling in the Patria case was, eventually, voided by a unanimous decision of the Constitutional Court. The Constitutional Court found that the defendant had been convicted of an abstract criminal act, that the judges at all instances violated the principles of lex certa, lex scripta and lex stricta in criminal law and that, furthermore, Mr Masleša as the President of the Supreme Court and of the trial chamber himself also violated the requirement of impartiality and hence the constitutional guarantee of a fair trial. ${ }^{75}$ However, in response to the Constitutional Court's decision, the Supreme Court argued that the latter simply arrived at a different interpretation of the law, while Mr. Masleša averred that he would have again acted the same. In a deeply politically split Slovenian environment, this reaction of the leadership of the Slovenian judiciary signalled an absolute lack of any self-criticism, refusal to take responsibility to foster justice more perfectly in the future. This has had a disastrous effect on the reputation of the Slovenian judiciary, which even the traditionally silent Slovenian legal academics did not hesitate to warn about. However, the blame for its sinking reputation the judiciary apportioned to the very few judges who publicly warned against this negative and unacceptable practice.

The most vocal with regard to the worrisome state of the Slovenian judiciary was Jan Zobec, then a justice at the Slovenian Constitutional Court. In his article, which was publicly condemned by the then President of the Supreme Court, Mr Masleša, for having opened the Pandora's box of discreditation of Slovenian judiciary, ${ }^{76}$ he stressed:

'The paramount problem of the Slovenian judiciary is the judiciary itself. First of all, the politics residing inside it, which has been preserved as part of the heritage of the totalitarian era in form of obstinate mental patterns firmly rooted in the old regime, expressing itself in collectivist and corporatist mindset. There, in the judiciary, this mind-set (as one form of the parallel, concealed, or deep state) thrives and feeds itself in terms of mode de pense, values and worldviews thanks to institutional closure and complacency. In a normal state with established democratic tradition and legal culture this would engender positive effects - it would foster what would already be there: internally, mentally independent judiciary. Unfortunately, in Slovenia it is also being fostered what there already is: anything but an intellectually autonomous and independent judiciary. 'Free riders', those who dare to think independently and critically (which ought to be inherent to each and every judge's intellect) are

\footnotetext{
${ }^{75}$ Constitutional Court Up-879/14, Up-883-14, Up-889/14 (April 20, 2015).

${ }^{76}$ See, President of the Supreme Court, Branko Masleša, addressing the Slovenian judges at the annual event "Days of Judiciary", official report available at: <www.sodisce.si/vsrs/objave/2014060616053789/> accessed 11 November 2014.
} 
side-lined, isolated and stigmatized as conflicting, litigious and simply weird individuals. $^{77}$

According to judge Zobec it

"therefore comes as no surprise that such an 'independent' judiciary is presided by 'a secret favourite of judges' - like judiciary, like its President (who is autonomously chosen by the judges who, thus, also deserve him)... [As a result...]: "The politics needs to do nothing, it needs not to impact on the judiciary in anything or with anything in order to submit it to itself and to put it under its influence for the time to be. This influence is already there, inside the judiciary, and it has, so to speak, been always there."78

As a consequence, Slovenian judiciary is still widely regarded as a strong ally of the postcommunist retention elite. ${ }^{79}$ It has been argued, that the courts have, unable to withstand the strong political pressure, through legal enforcement furthered not the rule of law but partisan political interests. ${ }^{80}$ Against this backdrop, it becomes also easier to understand why the public trust in the judiciary has been in a persistent decline since $2007^{81}$ and is today the lowest among all the Member States of the European Union, with only $16 \%$ of Slovenian citizens expressing their trust in the judiciary. ${ }^{82}$ The introduction of the judicial self-government in form of the Judicial Council has not alleviated these concerns, it might have even exacerbated them. This has certainly been the case in the recent appointment of the new President of the Supreme Court, Mr Damijan Florijančič, after the mandate of Mr Masleša had expired.

To provide a better understanding of a dwindling legitimacy and public distrust in the judiciary in Slovenia it is necessary to understand the historical problematique surrounding the appointment of the presidents of the Supreme Court. While the president of the Supreme Court represents and symbolizes the Slovenian judiciary as a whole, it has been one of the most symbolically and institutionally undermined statuses in Slovenia. The first president of the Supreme Court in the independent Slovenia was simply the last president

\footnotetext{
77 Jan Zobec, Mehki trebuh slovenskega sodstva, Delo (Dec. 8, 2012), www.delo.si/mnenja/gostujoce-pero/mehkitrebuh-slovenskega-sodstva.html (author's translation).

${ }^{78}$ Id.

${ }^{79}$ Bugarič, supra note 63 , at 13.

${ }^{80} / d$.

${ }^{81}$ Miro Haček, (Dis)trust into the Rule of Law in Slovenia, 4 PolitiCal PreferenCES 9, 19 (2013).

${ }^{82}$ Special Eurobarometer 461: Designing Europe's Future, http://ec.europa.eu/commfrontoffice/publicopinion/ index.cfm/ResultDoc/download/DocumentKy/78720.
} 
of the Supreme Court in the Socialist Republic of Slovenia. Ms. Francka Strmole, a high communist functionary, stayed in office till 1993. Thereafter the Supreme Court has had great difficulties in filling the position of its President. It has thus happened already three times that the President was not elected in good time. The Supreme Court was thus without a President first for three years, then for nine months and most recently for three months. The last round of appointment however, was turned into a farce, because of the way the Judicial Council conducted the nomination procedure.

To recall, the President of the Supreme Court is appointed by the National Assembly upon the proposal of the Minister of Justice. The latter proposes a candidate that has been recommended by the Judicial Council after having received the opinion of the Supreme Court sitting en banc. In the case of the appointment of the current President of the Supreme Court, Mr. Damijan Florjančič, the Supreme Court sitting en banc first proposed Mr Rudi Štravs as a candidate for its president to the Judicial Council. However, the latter refused Mr Štravs without stating any reasons. Upon fierce protests by a Supreme Court judge ${ }^{83}$ and some academics, ${ }^{84}$ the president of the Judicial Council, who failed to attend this important session, stated that no coherent statement of reasons could be given as the opinions on the candidate had been so much divided. ${ }^{85}$ Consequently, the Minister of Justice decided not to appoint Mr. Štravs, since he did not receive the joints support of the Supreme Court and the Judicial Council. As a result, a new call was issued and Mr. Štravs, somehow defiantly, decided to run again. This time the Supreme Court en banc, while reaffirming its initial support of Mr. Štravs, decided to give its preference to another candidate: Mr. Florjančič. Both names were then sent to the Judicial Council, sitting in the same composition. The Judicial Council now decided to support Mr. Štravs, i.e. the very same candidate that it had turned down in the first round. In so doing, the Judicial Council again voted against the candidate chosen by the Supreme Court, once more failing to provide any justification for its decision.

However, this time around the Minister of Justice, despite the lack of a joint support by the Judicial Council and the judiciary for any of the candidates, proposed Mr. Florjančič to the National Assembly. While Mr. Florjančič was thus, finally, elected, it is clear that the entire process has been conducted in an extremely non-transparent manner, without any reasons given in favour or against the candidates by the Judicial Council. This has created an impression of an overall arbitrariness and has left a huge negative mark on the Judicial Council as well as on the thereby elected President of the Supreme Court, whose authority has thus been marred from the outset. Barbara Zobec, a Supreme Court Justice, publicly

\footnotetext{
${ }^{83}$ Barbara Zobec, Ponižano Vrhovno sodišče, Finance (Sept. 19, 2016).

${ }^{84}$ Matej Avbelj, Izbiranje predsednika Vrhovnega sodišča - slovenski sodni svet je farsa, Finance (Sept. 19, 2016); Matej Avbelj, Bo sodni svet zdaj odstopil?, Finance (Dec. 17, 2016).

${ }^{85}$ Marko Novak, President of the Judicial Council in Odmevi, RTV SLO.
} 
protested, referring to David Kosar's analysis of the Slovak Judicial Council, that this particular incident demonstrates that in Slovenia too the Judicial Council has been created to be captured. ${ }^{86}$

This particular example of Judicial Council's activity without giving reasons amenable to a critical review in a public debate, strengthened the objections of unaccountability of the Slovenian judiciary. The question of accountability has been notably in the shadow of the judicial independence that the Slovenian judiciary has been preoccupied with. This has prompted the political actors, the general public as well as some experts into observing that the independence has been used as a proxy for avoiding accountability. The Slovenian judiciary has been described as conceited, unable to develop its own degree of sound selfcriticism, ${ }^{87}$ and even less to cope with an external public expert or political critique. ${ }^{88}$ However, when the pressure becomes insurmountable, as it has been the case with a revelation that the Slovenian judiciary simply lost, or failed to declare, hundreds of wills, ${ }^{89}$ "the system", rather than the actually responsible individual actors have been blamed for the scandal. In a manner reflecting best the understanding of individual accountability in the judiciary, the enforcement of individual accountability was said to be counterproductive. Rather than remedying the malpractices, it would, by installing fear in those responsible, prompt them into hiding their misdeeds. ${ }^{90}$ After all, the acting President of the Supreme Court commented on the occasion of the lost wills scandal, ${ }^{91}$ the judiciary too "is subject to the right to be forgotten, of sorts."

Marko Šorli, the former Vice President of the Supreme Court and a current Justice of the Constitutional Court Justice, argued that the lack of accountability is a systemic feature of the Slovenian judiciary stemming from the pre-modern model of judicial self-government which perpetuates the real-socialist strict hierarchical model of administering the courts. ${ }^{93}$

\footnotetext{
${ }^{86}$ Barbara Zobec, supra note 83.

${ }^{87}$ To this result see also Mateja Končina Peternel, Moč in avtoriteta sodnikov morata postati del nacionalne kulture, 33 PRAVNA PRAKSA 3 (2015).

${ }^{88}$ See also Tomaž Pavčnik, Kaj lahko sodstvo stori za ohranitev trajnega mandata?, 46 PRAVNA PRAKSA 33 (2011).

${ }^{89}$ The media reported that since between 1945-1991 4384 wills were lost, and since 1991 additional 1000.

${ }^{90}$ Andreja Lončar, Sodišču ne zaupajte svoje oporoke!, SIOL, http://siol.net/novice/slovenija/sodiscu-ne-zaupajtesvoje-oporoke-427307.

91 Between 1945 and 1991 the Slovenian judiciary failed to declare 4384 wills that were deposited by individuals at the courts to be declared in case of death. Almost additonal 1000 wills have not been declared since 1991 . The judiciary simply displaced those wills and the entitled successors were hence deprived of their hereditary rights. The "system « rather than any actual individual has been blamed for this legal scandal. See Andreja Lončar, Sodišču ne zaupajte svoje oporoke, https://siol.net/novice/slovenija/sodiscu-ne-zaupajte-svoje-oporoke-427307.

${ }^{92} / d$.

${ }_{93}$ Marko Šorli, Neučinkovit sodni sistem - uspešno vodenje?, 3 PRAVNA PRAKSA 3 (2013).
} 
According to him, the presidents of the lower courts perform their duties only formally, while decisions are de facto taken at the peak of the hierarchy at the Supreme Court. Eventually, no one is accountable for the malfunctioning judiciary; as those wielding de facto powers are formally unaccountable, while those who are formally accountable cannot be responsible for the decisions practically made elsewhere. This strictly hierarchical, administrative structure resembling organization also curtails the individual independence of judges and makes them accountable to their superiors. This accountability is not just formal, but not infrequently grows into informal dependency, which translates into an overall lack of internal independence of judges, typical for postcommunist countries. ${ }^{94}$ For the superior judges do not control just the quality of decisions of those below them, by exercising the appellate review, they also decide on the fate of their careers by sitting in the Personnel councils, as well as on the variety of benefits (such as continuing education, attendance at conferences etc.) that could be used to further, or not, their careers. Jan Zobec, presently Supreme Court Justice, has described this situation as an example of a judicial oligarchy, closely resembling what Djilas has described as a new class. ${ }^{95}$ Accordingly, the ruling judicial elite conceives of itself as being chosen for their interest, clan or class belongingness, rather than for their commitment to the rule of law. ${ }^{96}$ The members of the judicial oligarchy cherish those by whom they were appointed and who provide them with advantages and tiny privileges - such as lectures at judicial schools, appearance in the media, support for their undeserved promotion (etc.), or who simply tolerate their incompetence. ${ }^{97}$

These critiques by the members of the judiciary themselves have had a strong echo among the general public. The Judicial Council, however, has largely ignored them or it has resorted to its traditional, but essentially decontextualized and consequently emptymeaning mantra of importance to respect the independence of judges and the judiciary as a whole. Other than the members of the alleged judicial oligarchy who felt directly affected by these remarks, ${ }^{98}$ the judiciary too has largely ignored the problem. Internally, behind the closed doors, however, the Supreme Court's Annual conference 2017 was dedicated to the question of "unruly judges", facing a hard dilemma whether their public statements are still protected by the freedom of expression or they should be subject to disciplinary

\footnotetext{
${ }^{94}$ See, in particular, Alan Uzelac, Survival of the Third Legal Tradition, 49 SUPR. CT. L. REV. 377-396 (2010); Alenka Kuhelj \& Bojan Bugarič, A Day in the Life of a Post-Communist Europe, 8 THE HAGUE JOURNAL OF THE RULE OF LAW 183 (2016).

${ }^{95}$ Milovan Dillas, New Class: An Analysis of the Communist System (1957).

${ }^{96}$ Jan Zobec, Sodniški novi razred, Finance (Aug. 22, 2016).

${ }^{97} / d$.

${ }^{98}$ Nina Betetto, Generali in vojaki, Finance (Aug. 28, 2016).
} 
procedures instead. ${ }^{99}$ It appears that, eventually, the decision has been made that for now the "unruly judges" will not be subject to any sanctions.

Similarly, those judges who have perverted their accountability ${ }^{100}$ have never been subject to any sanctions either. Since 2003, the Judicial Council on the basis of the then amended Courts Act adopted a system of evaluation of judges that has mostly been based on the quantified criteria, the so-called judicial norm. ${ }^{101}$ As isolated judicial critical voices have warned, this system of judicial statistics has been manipulated, abused by judges, sometimes in a direct violation of judicial ethics, by all sorts of 'creative' means and techniques so that the productivity of a judge would appear much higher than his or her actual substantive, qualitative contribution to the law and dispute-resolution was. ${ }^{102}$ In a response to this malpractice, in 2015 the Judicial Council adopted new criteria for evaluating judges, emphasizing quality over quantity of the judge's work. ${ }^{103}$

However, the reputation of the Slovenian judiciary has already been tarred. The perception has been growing that the judiciary is a self-regulating and self-interested caste, which uses the constitutional guarantee of independence to maximize its own particular, mostly welfare interests. ${ }^{104}$ Cases of open conflict of interests between judges and parties in the cases involving large assets ${ }^{105}$ and even criminal activities by judges ${ }^{106}$ have led the public and the political sphere to demand a revocation of the judicial tenure system, on the basis of which the office of a judge in Slovenia is permanent. While the expert community has strongly opposed this move, it has simultaneously called for strengthening the accountability of judges. The judges in Slovenia have been said to be subject to the most

\footnotetext{
${ }^{99}$ For an analysis, see Matej Avbelj, Nova era ali po Masleši Masleša?, Finance (Apr. 29, 2017).

${ }^{100}$ For a description of the phenomenon "of output perversion of accountability" more generally, see Kosar, supra note 8 , at 68-72.

${ }^{101}$ See also Vavken, supra note 40 , at 107-108.

102 Tomaž Pavčnik, Ta je zoper nas, 9 PRAVNA PRAKSA 33 (2014).

${ }^{103}$ Vavken, supra note 40, at 118; Sodni svet RS, Merila za kakovost dela sodnikov za oceno sodniške službe (2015).

${ }^{104}$ One such notorious example was that of a judge who was appointed as a secretary general of the Government. While his judicial status was stayed, he also acted as an advocate in a case of his wife, filing a motion requesting all judges in Slovenia to recuse themselves as they are biased against him. The affair resulted in his stepping down from the governmental office. See Simona Toplak, Afera Cerarjev generalni sekretar Darko Krašovec: sodnik, ki ne priznava sodišč, žena, ki ne plačuje davkov, Finance (June 10, 2016) https://www.finance.si/8846026.

105 The so-called affaire "Bankruptcy friends" in which the judges, lawyers and bankruptcy managers were partying together, exchanging presents etc. remained unsanctioned by the personnel councils, see https://www.rtvslo.si/crna-kronika/prijatelji-v-stecaju-brez-sankcij-za-vpletene-upravitelje-in-sodnike/314894.

${ }^{106}$ The case of the Judge of a District Court of Celje.
} 
comprehensive and frequent supervision of their work. ${ }^{107}$ They are accountable in disciplinary and criminal terms. They are subject to the review by the appellate jurisdiction and can be put under special supervision by the president of the court if a judge is believed to be systemically underperforming both in terms of quantity and quality of his or her work. This special supervision is mandatory if required by the president of the superior court, President of the Supreme Court or by the Minister of Justice. ${ }^{108}$ However, in practice the accountability enforcing procedures remain very few, so that a notable gap exists between a de jure and a de facto accountability. ${ }^{109}$

The low legitimacy of the Slovenian judiciary, its (perceived) absence of independence, allegations of politicization and reluctance to take responsibility and to enforce accountability, increased the demands for transparency. This has, again, hit at the reluctance of the judiciary, ${ }^{110}$ supported by conservative incrementalism of the Judicial Council. $^{111}$ The latter has, in principle, spoken in favour of transparency, but it has simultaneously called for cautiousness, in order not to be reforming too much at once. However, the initially few expert voices, supported by the general public, demanded the publication of all decisions of the courts, so that they could be publicly discussed and critically evaluated by the academia. Judges names should be published too ${ }^{112}$ and the press should be allowed to publish their photos. Finally, even the ordinary judges, at least at the Supreme Court, would need to be allowed to write dissenting or concurring opinions. The judiciary, especially the leadership of the Supreme Court, has tried to slow down this development as much as possible, ${ }^{113}$ but the Ministry of Justice, also subject to the critique of the Judicial Council, has made a strong case for a greater transparency in judiciary. This is important because it is the transparency which in practice creates the conditions that foster a de facto accountability and independence of judges, whose faces, names and expertise is finally at the disposal of the expert community and of the general public, in whose name, after all, the judicial decisions are eventually made. However, most of the proposals of the Ministry of Justice, including the publication of dissenting opinions at the Supreme Court as well as the so-called Judicial Supervisor, an application which

\footnotetext{
${ }^{107}$ Vavken, supra note 40, at 77, quoting the then Vice-President of the Supreme Court.

108 Judicial Service Act, Arts. 79a,b,c.

${ }^{109}$ See, e.g., an interview with the former President of the Supreme Court, Mitja Deisinger, who in 2000 (still) explained that the data on the initiated disciplinary procedures are classified and that also in other countries such procedures are extremely rare. Bojan Kukec, Slovensko sodstvo na poti v Evropsko unijo: intervju s predsednikom Vrhovnega sodišča RS Mitjo Deisingerjem, 6 ODVETNIK 3 (2000.

${ }^{110}$ See, e.g., Nina Betetto, Koliko neodvisnosti je dovolj?, 48 PraVNA PRAKSA 3 (2015).

${ }^{111}$ See, e.g., Judicial Council, Sodstvo je velik, vendar zelo občutljiv sistem, 7-8 PRAVNA PRAKSA 3-4 (2006).

${ }^{112}$ See, e.g., Blaž Mrva, Za objavo imen sodnikov v objavljenih sodbah, 6-7 PRAVNA PRAKSA, 21 (2012).

${ }^{113}$ For a critique, see Matej Avbelj, Slovenski pravosodni meritokratski deficit, lus kolumna (March 13, 2017).
} 
would enable the publication of all first instance rulings of the courts, at the time of writing remained unrealized.

It follows from the above discussion that the Judicial Council as a constitutionally mandated body of judicial self-government in Slovenia has so far had a relatively limited impact on the independence, accountability, legitimacy, transparency of and confidence in the judiciary. As we have seen, there have even been cases in which the (in)action of the Judicial Council has affected negatively the values specified. ${ }^{114}$ The main reasons for this limited contribution of the Judicial Council rest in the fact that its formal competences have not been met by the actually existing, material capacity for executing them in practice. The Judicial Council has traditionally been under-institutionalized, ${ }^{115}$ understaffed and underfunded. ${ }^{116}$ The epicentre of the judicial self-government has therefore remained elsewhere, in the hands of the presidents of the courts and, the President of the Supreme Court in particular. The system has increasingly adopted the characteristics of judicial corporatism, which has been due to its oligarchic structure also susceptible to, especially informal, political influences, while giving the impression of de jure impeccability of the overall system. ${ }^{117}$ This de jure polished-up image however has had considerable and growing difficulties in explaining the mounting number of convictions of Slovenia before the ECtHR ${ }^{118}$ and to respond to the external reports, which have demonstrated that in comparative terms the Slovenian judiciary is expensive, very inefficient, featuring the highest number of judges per capita in Europe ${ }^{119}$ and at the same time enjoying one of the lowest ratings in public trust. ${ }^{120}$

The seemingly politically motivated trials, the proverbial incapacity of the judiciary to sanction dangerous forms of crime, white collar crime, corruption cases and, in particular, cases of banking and economic criminality created an increasing impression of an overall failure of justice in Slovenia. This feeling has been reinforced by a growing perception of

\footnotetext{
${ }^{114}$ See also Jernej Letnar Černič, Med Scilo in Karibdo, Ius kolumna (Sept. 16, 2016).

${ }^{115}$ Marko Novak, Institucionalna podhranjenost slovenskega sodnega sveta, 23 PRAVNA PRAKSA 17 (2013).

${ }^{116}$ See Marko Novak, Navidezna moč slovenskega Sodnega sveta, lus kolumna (July 4, 2016).

117 The members of the Judicial Council have, however, denied that, see Irena Vovk, Zavrnili očitke o cehovski solidarnosti, 38 PRAVNA PRAKSA 4-5 (2003).

${ }^{118}$ By 2016 Slovenia has been convicted by European Court of Human Rights in 341 cases, which makes it a leading country in terms of the number of violations found per capita.

${ }^{119}$ The huge number of judges is a legacy of a communist past and a result of a failed attempt to improve the efficiency of judiciary in Slovenia by increasing the number of judges. The latter was done as part of the Lukenda program in response to the eponymous ruling of the European Court of Human Rights which proclaimed the violation of the right to a speedy trial as a systemic problem in Slovenia (Lukenda v. Slovenia, no. 23032/02).

${ }^{120}$ See, recently, European Commission, Justice Scoreboard 2016.
} 
judicial bias in favour of those with power, either economic, political or both, while the common people have to endure the lengthy trials, where justice is either delay or denied to be eventually found only in Strasbourg. The centre-right part of the political spectrum started to use this popular dissatisfaction with the judiciary, labelling it the System of Injustice [Krivosodje], as part of its political fight which could in the future pave the way to a further institutional undermining of the already faltering judiciary. The judiciary, on its behalf, has reacted defensively, even more playing down the objective problems that it internally has, while the judicial elite has used this opportunity to consolidate and strengthen its position further, making any change, in particular of a structural character, increasingly unlikely. In all of this, the Judicial Council has played a relatively passive role, being effectively governed by judges, it has satisfied itself with a de jure existence of the constitutional values regulating the status of the Slovenian judiciary, by paying very little or even no attention how these values are actually effectuated in practice.

\section{Repercussions of Judicial Self-Government for the Principle of Separation of Powers and the Democratic Principle}

The Constitution of the Republic of Slovenia in 1991 for the first time after the WWII introduced the system of separation of powers. Article 3 of the Constitution lays down the principle of democratic legitimacy-chain, according to which in Slovenia power is vested in the people who, as citizens, exercise it directly and through elections, consistent with the principle of the separation of legislative, executive, and judicial powers. ${ }^{121}$ The Constitution thus introduced a systemic change in the functioning of the state. Most importantly, an independent Constitutional Court with actual powers was created. It acts as a check on the arbitrariness or human rights violations by the judiciary in the individual cases as well as a guarantor of legality and constitutionality against the potential encroachments by the legislature or the executive branch. Recently, the ordinary judiciary has been voicing protests that the Constitutional Court has been overstepping its competences, interfering with the powers of the ordinary courts, and in particular with the rulings of the Supreme Court on an increasingly unconvincing, sometimes even arbitrary grounds. ${ }^{122}$ Secondly, the judiciary was established as an independent power, free of direct political influence of the ruling party. Finally, while in the relationship between the parliament and the executive several elements of the system of undivided power have been preserved, this relationship too has moved more closely to a model of government typical of the consolidated parliamentary systems. ${ }^{123}$

\footnotetext{
${ }^{121}$ Art. 3 Constitution.

${ }^{122}$ See, e.g., Vladimir Balažic, Arbitrarnih odločb vrhovnega in ustavnega sodišča enostavno ne sme biti, Delo (June 10, 2017).

${ }^{123}$ Occasionally, however, relicts of the old system resurface in practice. Such was a "Commitment between the Government and the Judiciary to Improve the State of Judiciary" agreed in 2013 http://www.mp.gov.si/fileadmin/mp.gov.si/pageuploads/mp.gov.si/PDF/131002_podpisana_ZAVEZA.pdf.
} 
The establishment of a Judicial Council as a key body of judicial self-government cannot be seen as a significant change in the system of separation of powers on its own. It is rather instrumental to the overall constitutionally mandated objective of ensuring the existence of a judiciary as an independent branch of power. The new Constitution has thus introduced a model of judicial (self)-government in which the courts are separated from other institutions of the state (the separation of institutions), they exercise separate, i.e. judicial function (the separation of functions) which can be only conducted by judges that cannot take part in any other institution of the state (the personal incompatibility). On this basis a dense system of checks and balances between the courts, the legislature and the executive has been created, with a Judicial Council playing an important role in its midst. ${ }^{124}$

The system of checks and balances is based on the principle of a democratic legitimacy chain. The citizens elect the National Assembly, which appoints the government, including the Minister of Justice. The Judiciary is an independent branch. The courts and judges, however, rule in the name of the people, to whom they are, eventually, accountable by way of adhering to the highest constitutional standards, valid laws, professional rules and principles governing the overall judicial integrity. The judiciary itself is foremost called upon to enforce these standards, but the external control by the legislative and the executive branch is ensured via the Judicial Council. The majority of the Judicial Council are judges, elected among themselves, which is said to be a guarantee of judicial independence. The National Assembly, as a representative of the people, appoints the remaining members and in so doing ensures a democratic control in the Judicial Council itself. The democratic control of the judiciary by the people represented in the National Assembly in Slovenia is strengthened further by the fact that it is the National Assembly which appoints the judges. In recent years the National Assembly, as we have seen above, has indicated that it understands its appointment powers not to be only formal, but that a substantive review and even the refusal of the candidates for a judicial post is a real possibility.

The National Assembly, upon the proposal of the government, also adopts the legal framework for the functioning of the judiciary and it ensures, again by way of governmental proposals, that the judiciary's share in the national budget suffices for a viable exercise of its constitutional powers. The overall organization of the judiciary is decided on the axis between the President of the Supreme Court, the Minister of Justice with a, typically, consulting involvement of the Judicial Council. Almost any change in the structure and functioning of the judiciary in Slovenia must be translated into a statute and has to win a legislature's approval. Both the judiciary and the Judicial Council have objected that the legislative changes are too numerous, absent of an overall vision of the

${ }^{124}$ See, e.g., Marijan Pavčnik, Sodstvo, delitev oblasti in ustava, 6-7 PODJETJE IN DELO 1513-1522 (2006). 
functioning of the judiciary and without the latter being adequately involved in the preparation of the legislation. ${ }^{125}$

As it has been explained in Part II, in relationship with the National Assembly the Judicial Council has the power of nomination and a duty of reporting about its activities and about the overall state of the Slovenian judiciary. In relationship with the Minister of Justice, the Judicial Council provides opinions and has a number of rule-making powers to which either the consent or the opinion of the Minister of Justice is required. However, the role of the Ministry of Justice, in particular with regard to the selection of judges, has been diminished through successive legislative amendments in favour of the Judicial Council. ${ }^{126}$ In relationship with the judiciary, the Judicial Council makes a selection of candidates for a judicial service, appoints the presidents of the courts (other than the Supreme Court), supervises the management of the judiciary, adopts quality standards for the functioning of the judiciary, of the personnel councils etc. It also acts as an appellate instance in the disciplinary and other procedures, and it is consulted in other issues related to court management provided by the law. The Ministry of Justice is politically responsible for the functioning of the judiciary in Slovenia. It proposes the candidate for the President of the Supreme Court, drafts and oversees the legislation, prepares and monitors the use of the budget, oversees the judicial statistics and can administratively supervise the management of cases as well as the overall governance of individual courts.

\section{E. Conclusion}

If our focus was limited only to a legalistic functioning and organization of the checks and balances with regard to the judiciary and its self-government an almost unobjectionable image of Slovenian judiciary would emerge. The same could be said of its democratic predicaments, in particular the requirement that also the judiciary is, eventually, both in its output as well as input legitimacy in service of and dependent on the people. However, this paper has deliberately eschewed the exclusively legalistic approach, which too often prevails in legal scholarship concerned with judicial governance. The paper has attempted, within what its limited scope has permitted, to situate the system of judicial selfgovernment in the Slovenian socio-political context in order to provide an insight into how the judicial self-government really works and to what an extent it falls short of the normative ideals prescribed to it in the Slovenian positive law.

We have observed that there exists a yawning gap between the judicial self-government on books and the one that takes place in the actual practice. The remnants of the communist totalitarian past and the dense formal and informal networks in a relatively small legal and political Slovenian community have been used to manipulate the legal

\footnotetext{
${ }^{125}$ See the report by Irena Vovk, Nedomišljene sodne reforme, 24-25 PRAVNA PRAKSA 37 (2013).

${ }^{126}$ See, e.g., Aleš Zalar, Minister za pravosodje, Sodni svet in sodniki, 6-7 PODJETJE IN DELO 1280 (2002).
} 
system of judicial self-government so to detract rather than to contribute to the values and principles associated with judiciary in a well-functioning constitutional democracy. 
